\title{
INOVASI DAN PEMBERDAYAAN MASYARAKAT MELALUI KESENIAN DI DESA KEDU KECAMATAN KEDU KABUPATEN TEMANGGUNG
}

\author{
Supriyanto \\ Jurusan Tari \\ Fakultas Seni Pertunjukan ISI Surakarta
}

\begin{abstract}
Abstrak
Pemberdayaan Masyarakat Melalui Kesenian Di Desa Kedu Kecamatan Kedu Kabupaten Temanggung merupakan kegiatan pengabdian kepada masyarakat yang dilakukan oleh dosen dan mahasiswa melalui progran Kuliah Kerja Nyata (KKN). Kegiatan itu merupakan salah satu dari Tri Dharma Perguruan Tinggi terutama pengabdian ilmu kepada masyarakat. Pemberdayaan masyarakat melalui kesenian akan menumbuhkan masyarakat merasa memiliki terhadap kesenian tradisionalnya. Dengan diterjunkannya mahasiswa ISI Surakarta ke lapangan KKN yang didampingi oleh dosen maka mahasiswa dapat mengamati, menganalisis dan dapat menemukan solusi agar masyarakat dapat melestarikan dan mengembangkan potensi kesenian yang dimiliki. Untuk dapat menumbuhkan masyarakat memiliki kepedulian terhadap keseniaannya diperlukan beberapa metode dan langkah-langkah yaitu metode pendekatan, sosialisasi dan koordinasi. Perubahan kehidupan masyarakat sangat berpengaruh pada perubahan sosial, tata nilai, yang akan mempengaruhi perubahan dan perkembangan kesenian. Perubahan nilai kesenian akan ditentukan oleh perubahan masyarakat pendukungya. masyarakat berpengaruh pada kreativitas seni, sehingga seni tradisional selalu berkembang, berubah, sesuai dengan perubahan masyarakat penggunanya. Seni tradisional akan menjadi bagian dari kehidupan masyarakatnya. Hasil pelaksanaan kegiatan pengabdian kepada masyarakat, mahasiswa memberikan andil yang sangat besar bagi masyarakat di Kelurahan Kedu, Kecamatan Kedu Kabupaten Temanggung. Masyarakat menjadikan kesenian sangat penting bagi kehidupan. Dengan adanya mahasiswa KKN di wilayah Kedu ini dapat menumbuhkan kecintaan masyarakat terhadap kesenian yang dimilikinya. Kesenian akan tetap lestari dengan perubahan dan perkembangannya.
\end{abstract}

Kata kunci: Pemberdayaan, Masyarakat, Kesenian, Kedu.

\begin{abstract}
Community Empowerment through Art in Kedu Village, Kedu Subdistrict, Temanggung, is a community service carried out by lecturers and students through the Community Service Program (KKN) program. The activity is one of the Tri Dharma of Higher Education, especially community service. Community empowerment through arts will foster community ownership of traditional arts. By sending ISI Surakarta students to the Community Service Program (KKN) field accompanied by lecturers, students can observe, analyze and find solutions so that the community can preserve and develop their artistic potential. To be able to grow the community has a concern for kesenianya required several methods and steps namely the method of approach, socialization and coordination. Changes in people's lives greatly affect social change, values, which will affect changes and the development of art. Changes in the value of art will be determined by changes in supporting society.
\end{abstract}




\section{Abdi Seni Jurnal Pengabdian Kepada Masyarakat}

society influences the creativity of art, so that traditional art always develops, changes, in accordance with changes in the user community. Traditional art will become a part of people's lives. The results of the implementation of community service activities, students give a very large contribution to the community in Kedu Village, Kedu District, Temanggung Regency. Society makes art very important for life. With the existence of Community Service Program (KKN) students in the Kedu region, it can foster community love for their art. Art will remain sustainable with its changes and developments.

Keywords. Empowerment, Community, Arts, Kedu.

\section{. LATAR BELAKANG}

Sebagai sebuah perguruan tinggi, Institut Seni Indonesia (ISI) Surakarta memiliki tugas dan fungsimelaksanakan TriDharma Perguruan Tinggi, yakni pendidikan dan pembelajaran, penelitian, dan pengabdian kepada masyarakat. Salah satu bentuk pengabdian kepada masyarakat .Pengabdian kepada masyarakat ini dapat dilaksanakan oleh dosen dan mahasiswa dengan kegiatan Kuliah Kerja Nyata (KKN).

Pengabdian kepada masyarakat merupakan upaya mewujudkan kedekatan dan kepedulian perguruan tinggi terhadap stakeholder eksternal. Kuliah Kerja Nyata (KKN) merupakan suatu bentuk pengabdian kepada masyarakat yang dilakukan oleh mahasiswa. KKN merupakan suatu bentuk pembelajaran lapangan yang dilakukan oleh mahasiswa yang merupakan bagian aksivitas akademika, baik secara pribadi maupun kelompok. KKN juga sebagai bentuk pendidikan dengan cara memberikan pengalaman belajar kepada mahasiswa untuk dapat hidup ditengah-tengah masyarakat diluar kampus dan secara tidak langsung mengidentifikasi serta ikut mengalami masalah-masalah yang sedang dihadapi dalam kehidupan masyarakat.

Desa Kedu merupakan salah satu daerah yang berada di Kecamatan Kedu, Kabupaten Temanggung, Propinsi Jawa Tengah. Jarak dari kota Temanggung ke Desa Kedu kurang lebih 7 kilometer. Sarana transport di Desa Kedu sudah cukup memadai baik itu kendaraan roda dua maupun roda empat. Ruas jalan yang ada juga sangat bagus sudah beraspal dan cor blok. Disamping itu juga sepanjang jalan masuk kampung-kampung sudah ada penerangan dengan menggunakan sumber daya listrik. Batas wilayah desa sebelah utara Desa Ngadimulyo, sebelah selatan Desa Salamsari, sebelah timur Desa Candimulyo, sebelah barat Desa Danurejo. Desa Kedu memiliki luas wilayah 350,74 ha, yang digunakan sebagai pemukiman, persawahan, dan perkebunan. Mata pencaharian penduduk sebagian besar sebagai petani, bekerja sebagai buruh tani dan sebagian sebagai PNS (Monografi desa th 2017).

Desa Kedu memiliki beberapa fasilitas pendidikan yaitu sekolah TK ada 37 sekolahan, untuk SD ada 26 sekolahan, SMP ada 4 sekolahan dan SLTAada 3 sekolahan. Disamping itu Desa Kedu juga memiliki potensi objek wisata sejarah berupa makam KiAgeng Makukuhan dan Sendang Upas. Pengunjung objek wisata itu terhitung cukup ramai baik itu darimasyarakat Temanggung maupun dari luar Temanggung. Hal lain yang menjadi kekayaan budaya adanya upacara adat tradisi dan kirab budaya , serta beberapa kesenian yang hidup di Kedu.

Desa Kedu merupakan wilayah yang cukup tepat untuk dilakukan Kuliah Kerja Nyata mengingat potensi seni yang sangat besar yang dimiliki oleh daerah. Beberapa kelompok seni di antaranya adalah Ceklungan, Ketoprak, Kobrasiswa, Topeng Ireng, Warokan Putri, Soreng, Kuda Lumping, Capursari, Maulud, Rebana dan Dayakan. Antusias warga Kedu cukup tinggi, terbukti dari minat anak-anak untuk belajar seni. Anak-anak setingkat Taman Kanak-kanak (TK) maupun Sekolah Dasar (SD) kerap kali menari 
dalam perpisahan sekolah maupun acara Hari Ulang Tahun kemerdekaan Republik Indonesia. Kesenian di Desa Kedu lahir dengan kesederhanaan dan menjunjung tinggi kearifan lokal serta budayabudaya yang berkembang di masyarakat.

\section{a. Analisa Situasi}

Desa Kedu merupakan salah satu daerah yang terletak di Kabupaten Temanggung, Jawa Tengah. Memiliki luas daerah kurang lebih 350 hektar, yang terdiri dari 8 dusun dengan jumlah Rukun Warga sebanyak 8 dan Rukun Tetangga 43. Diantaranya Dusun Carikan, Dusun Sudagaran, Dusun Ngemplak, Dusun Irawanan, Dusun Makukuhan, Dusun Tawangsari. Dusun Kahuripan, dan Dusun Mbeji. Daerah yang memiliki pemandangan alam yang begitu luar biasa yakni pemandangan Gunung Sumbing dan Gunung Sindoro ini, tersimpan begitu banyak kearifan lokal seperti kesenian, tradisi masyarakat, hingga hasil alam yang begitu beragam.

Seni tradisi di desa kedu sangat begitu hidup, hal ini tampak dari penanaman rasa cinta terhadap kebudayaan khususnya kesenian pada anak-anak sejak usia dini. Bahkan masing-masing dusun bisa memiliki lebih dari satu komunitas kesenian yang berkembang hingga saat ini. Pertunjukan seni pun masih sering ditampilkan didesa ini.

Tidak hanya kesenian, didesa kedu juga terdapat situs wisata religi yang sudah terkenal, yakni makam Ki Ageng Makukuhan. KI Ageng makukuhan yang juga disebut Syeikh Maulana Taqwin adalah seorang wali yang ikut tergabung dalam anggota Dewan Santri, konon berasal dari generasi penerus Walisanga.

Salah satu icon lain dari daerah Kedu adalah Ayam Cemani. Hal yang menjadikan ayam cemani di desa Kedu ini berbeda dengan tempat lainnya adalah, terdapat warna hitam dikeseluruhan tubuh ayam, hingga ke dalam rongga mulut ayam, bahkan warnanya pun cenderung ke warna hitam pekat. Ini lah yang menjadikan keunikan tersendiri dari ayam cemani di daerah manapun.
Sama halnya dengan kota Temanggung yang memiliki sebutan kota tembakau karena mayoritas penduduknya menggantungkan mata pencahariannya dengan bertani tembakau, icon yang juga sangat melekat dengan desa Kedu adalah tanaman tembakau. Hampir sebagian besar mata pencaharian warga desa kedu sebagai petani tembakau dan juga pengrajin keranjang, untuk tempat panen tembakau. hal ini lah yang juga menjadikan tembakau begitu sangat dibanggakan di seluruh daerah Temanggung. lahan perladangan di daerah kedu ini pun, sebagian besar digunakan untuk ladang tanaman tembakau, walaupun tak jarang pula ladang digunakan untuk menanam berbagai macam sayur-sayuran.

\section{b. Potensi Kesenian}

\section{Kuda Lumping}

Kuda lumping juga disebut jaran kepang atau jathilan adalah tari tradisional Jawa yang menampilkan sekelompok prajurit tengah menunggang kuda. Tarian ini menggunakan properti tiruan kuda yang terbuat dari bahan bamboo atau bahan lainnya yang di anyam dan dipotong menyerupai bentuk kuda, dengan dihiasi rambut tiruan dari tali plastik atau sejenisnya yang digelung atau dikepang. Anyaman kuda dihias dengan cat dan kain beraneka warna. Tarian kuda lumping biasanya hanya menampilkan adegan prajurit berkuda, namun beberapa penampilan kuda lumping juga menyuguhkan atraksi kesurupan, kekebalan dan kekuatan magis, seperti memakan beling dan kekebalan tubuh terhadap deraan pecut. Tidak satupun catatan sejarah mampu menjelaskan asal mula tarian ini, hanya riwayat verbalyang diturunkan dari generasi ke generasi. Ada pula yang menyebutkan, bahwa tari kuda lumping menggambarkan kisah seorang pasukan pemuda cantik bergelar Jathil penunggang kuda putih berekor emas, serta memiliki sayap emas yang membantu pertempuran kerajaan Bentarangin melawan pasukan penunggang babi hutan dari kerajaan Lodaya pada serial legenda reog pada abad ke 8 . 


\section{Dayakan}

Seni kebudayaan dayaan/topeng ireng mengisahkan tentang perjuangan seorang pertapa untuk membuka lahan hutan untuk dijadikan sebagai tempat pemukiman, dimana dihutan tersebut terdapat manusia rimba. Seorang pertapa tersebut melawan para manusia rimba dan mengajari mereka untuk hidup sebagai manusia biasa, mengajak mereka membuka hutan, membuka lahan pertanian, dan mengajari seni bela diri. Kekompakan tari adalah hal yang paling diutamakan oleh para penari topeng ireng ini. Topeng Ireng sering juga disebut sebagai Tari Dayakan, hal tersebut dikarenakan kuluk/ topi yang digunakan hampir sama dengan topi yang dipakai oleh masyarakat suku Dayak. Dayakan sendiri di Desa Kedu dimainkan oleh 13 penari dan baru aktif 1 tahun yang lalu.

\section{Makam Makukuhan}

Tidak hanya kesenian, didesa kedu juga terdapat situs wisata religi yang sudah terkenal, yakni makam Ki Ageng Makukuhan. KI Ageng makukuhan yang juga disebut Syeikh Maulana Taqwin. Di samping itu, ia juga dinamakan Sunan Kedu karena telah menyebarkan agama Islam di daerah Kedu yang sekarang bertempat di Desa Kedu, Kecamatan Kedu, Kabupaten Temanggung. Sementara itu KiAgeng Makukuhan adalah seorang wali yang ikut tergabung dalam anggota Dewan Santri konon dari generasi penerus Walisanga.

\section{PERMASALAHAN MITRA}

Desa Kedu, Kecamatan Kedu Kabupaten Temanggung kondisi masyarakatnya masih menjunjung tinggi nilai-nlai adat dan kesenian rakyat setempat yang menjadi sasaran kuliah kerja nyata Mahasiswa ISI Surakarta . Dari uraian analisis situasi di atas maka mendapatkan permasalahan sebagai berikut :

1. Bagaimana menumbuhkan dan membangun potensi seni dalam realita kehidupan masyarakat Desa Kedu ?.
2. Bagaimana pemberdayaan masyarakat terhadap seni tradisi di Desa Kedu?.

\section{TUJUAN DAN MANFAAT}

Tujuan dari kegiatan ini, sebagai berikut :

a. Meningkatkan kesadaran dan kemampuan masyarakat terhadap potensi kesenian yang dimiliki

b. Meningkatkan kreatifitas dan rasa cinta masyarakat terhadap kesenian lokal.

Adapun manfaat dari kegiatan ini, sebagai berikut :

a. Memperoleh kesadaran dan kemampuan memberdayakan potensi kesenian yang dimiliki untuk peningkatan kualitas hidup.

b. Memperoleh pengalaman dalam menggali dan menumbuhkan potensi kesenian masyarakat sehingga mampu berpartisipasi aktif dalam pembangunan.

c. Memperoleh manfaat dari bantuan tenaga dan pikiran mahasiswa KKN dalam melaksanakan program pembangunan.

\section{METODOLOGI}

\section{Solusi yang ditawarkan}

Pengkajian dan pendampingan akan dilakukan dengan menggunakan metode kaji tindak dan tindakan kreatif inovatif. Sikap kreatif merupakan proses berpikir untuk melahirkan gagasan-gagasan baru, dan inovasi merupakan proses aplikasi gagasan untuk diwujudkan ke dalam suatu tindakan atau perilaku (Alfian, 1986:154). Langkah selanjutnya adalah proses pendampingan dengan mengembangkan garap kreatif kesenian rakyat. Beberapa repertoar ragam gerak dan ragam iringan disesuaikan dengan karakteristik dan kehendak kelompok. Pendampingannya menggunakan pendekatan sharing and sugestion secara dialogis dengan mengacu pada rancangan garap kreatif. Tujuan pendampingan agar kesenian 
rakyat Desa Kedu menjadi berkembang, lebih kreatif dan lebih bermakna dalam kehidupan masyarakat.

Beberapa langkah kegiatan yang ditawarkan dan metode yang diterapkan.

1. Mengupayakan pelatihan yang memiliki kapabilitas untuk meningkatkan variasi garap dan kualitasnya.

2. Pendampingan akan mengupayakan pembangunan citra dan karakteristik kesenian rakyat Desa Kedu sesuai dengan kehendak para anggotanya melalui kajian yang mendalam terhadap latar belakang kehidupan sosial budaya pendukungnya.

3. Pendamping akan membantu mensosialisasikan kepada generasi muda setempat mengenai nilai kearifan lokal dibalik kesederhanaan kesenian rakyat. Para generasi muda setempat diharapkan bersikap lebih dinamis dan reseptif terhadap kesenian rakyat yang dimiliki.

4. Pendampingan akan mengupayakan menejemen agar dikelola secara baik.

Pelaksanaan Pembimbing melakukan survey di Desa Kedu selama 2 minggu untuk mengetahui permasalahan-permasalahan, kebutuhan-kebutuhan dan alokasi penempatan mahasiswa. Pada minggu ke tiga pembimbing mengadakan pelatihan atau coutching terhadap mahasiswa di kampus tentang situasi dan kondisi Desa Kedu sebagai tujuan KKN. Pada minggu keempat dilakukan pemberangkatan mahasiswa yang dilepas oleh Ketua LLPMMPP ISI Surakarta. Pembimbing mendampingi mahasiswa sejak diberangkatkan hingga penyerahan kepada camat dan desa setempat. Penempatan akomodasi dirancang sesuai dengan persetujuan Lurah Kepala Desa dan Kadus serta diketahui oleh pembimbing. Secara berkala pembimbing melakukan pegawasan dan bimbingan agar pelaksanaan KKN berjalan dengan baik.

Dalam proses pelaksanaan kegiatan menggunakan metode pendekatan Rapid Assessment \& Planning Execution. Planning
Execution mahasiswa sebagai peserta pelaksanaan KKN, masyarakat dan perangkat desa melakukan dialog, diskusi pengembangan detail rencana kegiatan dan pelaksanaan kegiatan proses kegiatan KKN. Rapid Assessment sosialisasi dan mediasi pada instansi terkait diwilayah kerja Desa Kedu, Kecamatan Kedu serta perencanaan ulang detail kegiatan di lapangan. Waktu yang dijadwalkan adalah satu minggu pertama sejak kehadiran. Dua pendekatan merupakan satukesatuan cara yang digunakan untuk mempermudah proses pelaksanaan KKN. Model pendekatan ini relatif mudah diterapkan pada waktu mahasiswa KKN. Model pendekatan Rapid Assessment \& Planning Execution menjadi strategi pelaksanaan dilapangan.

Sebagai tambahan model pendekatan lain digunakan dalam lapangan untuk melihat situasi dan permasalahan-permasalan yang terjadi, antara lain(1). pendekatan sosial, ialah pendekatan melalui proses komunikasi dan interaksi kepada masyarakat atau guru-guru untuk menjelaskan maksud dan tujuan KKN, (2). observasi langsung ke tempat objek kegiatan atau instansi yang terkait guna mengetahui situasi secara langsung.

Dalam pelaksanaan direncanakan model kegiatan yang didasarkan pada informasi dari hasil observasi dan sosialisasi dengan masyarakat sekitar di desa Kedu.

Dengan adanya hasil informasi mempermudah untuk penyampaian kepada sasaran proses pelaksanaan KKN. Kegiatankegiatan yang akan dilakukan dirancang sederhana tetapi bermanfaat bagi masyarakat dan dapat dijangkau oleh mahasiswa Kuliah Kerja Nyata (KKN) dan dengan pertimbangan situasi objek, waktu, serta menyesuaikan lokasi yang terkait. Kegiatan Kuliah Kerja Nyata di Desa Kedu, Kecamatan Kedu, Kabupaten Temanggung dilakukan dengan menggunakan metode kegiatan sebagai berikut:

1. Metode pendekatan, merupakan langkah yang dilakukan mahasiswa untuk saling mengenal antara mahasiswa dengan warga dusun 
setempat. Pendekatan juga dilakukan untuk memahami objek, perkiraan jangkauan waktu, serta menyesuaikan dengan lingkungan masyarakat sekitarnya.

2. Metode Sosialisasi, dilakukan mahasiswa dalam berinteraksi dengan masyarakat Desa Kedu..

3. Menawarkan Program (mediasi), dilakukan mahasiswa untuk mendukung pelaksanaan KKN dengan menawarkan suatu rencana program kegiatan kepada masyarakat untuk memperoleh kesepakatan bersama sehingga permasalahan-permasalah yang terjadi dapat terselesaikan secara bersama.

4. Pelaksanaan program, mahasiswa melaksanakan program kegiatan yang telah dirancang dan disepakati bersama sesuai jadwal yang telah disusun.

\section{Partisipasi Mitra Dalam Pelaksanaan Program.}

a. Pembinaan, pembina mengarahkan peserta Kuliah Kerja Nyata (KKN) dan masyarakat tentang kreativitas seni tradisional kerakyatan agar berkembang dan mengikuti perubahan selera masyarakat.

b. Pelatihan, pembina mengawasi kegiatan Kuliah Kerja Nyata (KKN) mahasiswa dalam melatih kreativitas seni sesuai dengan kemampuan masyarakat. pelatihan meliputi Seni Karawitan, Seni Tari, Etnomusikologi dan Seni Teater, Kriya Seni, Seni Rupa Murni, Desain Komunikasi Visual, Desain Interior, Televisi dan Film.

c. Pentas seni dan pameran, melibatkan seluruh warga binaan Kuliah Kerja Nyata (KKN) dan masyarakat setempat.

\section{Target Luaran}

Hasil (output) yang ditargetkan dari kegiatan adalah;

1. Memperkaya variasi garap kesenian rakyat yang meliputi ragam gerak tari yang inovatif, gending dan kualitas garapnya.
2. Produk hasil pendampingan adalah:

1. paket sajian kesenian rakyat untuk hajatan.

3. Menajemen kesenian rakyat Desa kesenian menjadi tertata.

4. Artikel Ilmiah

Dampak (outcome) yang diharap dari kegiatan pendampingan adalah:

1. Peningkatan kreativitas garap dan produktivitas seni bagi anggota kelompok seni kesenian rakyat Desa Kedu

2. Peningkatan jalinan kerjasama hasil binaan.

3. Meningkatkan kesejahteraan bagi kelompok kesenian masyarakat Desa Kedu..

\section{PEMBAHASAN}

\section{a). Pelaksanaan Program}

Pelaksanaan program Kuliah Kerja Nyata (KKN) Institut Seni Indonesia Surakarta di Desa Geblog dilaksanakan selama 35 hari, dimulai dari tanggal 25 juli-25 Agustus 2018. Kelompok Kuliah Kerja Nyata (KKN) Desa Kedu melibatkan 15 mahasiswa - mahasiswi terdiri dua Fakultas yaitu Fakultas Seni Pertunjukan yang meliputi Seni Karawitan, Seni Tari, Etnomusikologi dan Seni Teater dengan Fakultas Seni Rupa dan Desain yang meliputi Program Jurusan Kriya Seni, Seni Rupa Murni, Desain Komunikasi Visual, Desain Interior, Televisi dan Film. Kuliah Kerja Nyata (KKN) dilaksanakan untuk melaksanakan salah satu Tri Dharma Perguruan Tinggi yaitu Pengabdian Kepada Masyarakat di Desa Kedu Kecamatan Kedu Kabupaten Temanggung.

Kegiatan Kuliah Kerja Nyata (KKN) dilaksanakan sesuai dengan program lembaga Pengabdian Kepada Masyarakat ISI Surakarta menyesuaikan dengan kebutuhan dilapangan dari mulai perancangan, persiapaan, pelaksanaan serta kendala-kendala yang dihadapi. Program kerja terdiri dari program kerja kelompok dan program kerja individu yang berjalan seiringan dalam pelaksanaannya. Kegiatan - kegiatan yang telah dilakukan meliputi beberapa tahapan sebagai berikut: 


\section{b). Tahap Pelaksanaan}

a. Sosialisasi

Kegiatan sosialisasi, merupakan tahapan awal yang dilaksanakan oleh panitia untuk memberikan informasi mengenai pelaksanaan kegiatan Kuliah Kerja Nyata (KKN). Sosialisasi dilaksanakan pada tanggal $08 \mathrm{Mei}$ 2018 di Teater Besar Institut Seni Indonesia (ISI) Surakarta. Dalam pertemuan panitia memberikan pengarahan dan informasi seperti lokasi Kuliah Kerja Nyata (KKN), gambaran umum mengenai keadaan daerah kegiatan yang akan dilaksanakan dan informasi mengenai rincian pembayaran serta akomodasi yang akan digunakan pemberangkatan, kegiatan dan penarikan.

b. Observasi, setiap kelompok mahasiswa yang telah ditentukan melakukan pendekatan dan survey lapangan sesuai dengan lokasi terpilih. Peserta Kuliah Kerja Nyata (KKN) dalam kelompok di Desa Kedu, Kecamatan Kedu, Kabupaten Temangung melakukan observasi di Desa Kedu dua kali pada tanggal 14 Juli dan 17 Juli 2018. Dari observasi diperoleh gambaran dareah, kondisi masyarakat, potensi kesenian, potensi sumberdaya manusianya.

\section{c). Pembekalan}

Seluruh mahasiswa-mahasiswi peserta mendapatkan pembekalan sebelum pemberangkatan ke lokasi. Pembekalan berlangsung selama 2 hari pada tanggal 19-20 Juli 2018 di Gedung F Kampus 1 Institut Seni Indonesia (ISI) Surakara. Dalam pembekalan mahasiswa mendapatkan banyak informasi untuk melaksanakan Kuliah Kerja Nyata (KKN). Mulai dari penyusunan program kerja, penjelasan lebih dalam mengenai lokasi masing-masing kelompok, berdiskusi mengenai akomodasi pemberangkatan dan kepulangan. Dalam proses pembekalan setiap peserta Kuliah Kerja Nyata (KKN) diwajibkan untuk hadir. Dalam pelaksanaan pembekalan juga dipertemukan dengan Dosen Pembimbing Lapangan
(DPL) untuk mendapatkan bimbingan dan arah yang dapat di jadikan pedoman.

\section{d). Penyerahan Peserta Kuliah Kerja Nyata (KKN)}

Penyerahan peserta dilaksanakan pada tanggal 25 agutus 2018 pagi dengan serangkaian yang harus di ikuti. Seluruh peserta melaksanakan apel pelepasan pertama di gedung Pendhopo Institut Seni Indonesia (ISI) Surakarta. Kemudian pemberangkatan dilaksanakan setelah apel selesai. DiTemanggung di selenggarakan upacara ceremonial penyerahan mahasiswa-mahasiswi Kuliah Kerja Nyata (KKN) Institut Seni Indonesia (ISI) Surakarta di Gedung Pertemuan di kantor Sekertaris Daerah (SEKDA) Kabupaten Temanggung, dilanjutkan dengan pemberangkatan ke desa masingmasing sesuai dengan lokasi.

Peserta di berangkatkan ke Desa Kedu dengan jemputan dari pihak desa dan bersama mobil Dosen Pembimbing Lapangan (DPL). Bertempat di Balai Desa Kedu, Dosen Pembimbing Lapangan (DPL) menyerahkan peserta Kuliah Kerja Nyata (KKN) kepada PJS Kepala Desa Kedu, untuk dapat melaksanakan kegiatan selama 35 hari dari mulai 25 Juli-30 Agustus 2018.

\section{e). Penarikan Kuliah Kerja Nyata Mahasiswa}

Berbagai kegiatan mahasiswa ditengah masyarakat di klasifikasikan sesuai dengan bidang studi yang diajarkan di kampus. Hasil akhir dari kegiatan mahasiswa dipentaskan dan dipamerkan bersamaan dengan perayaan peringatan Hari Kemerdekaan Republik Indonesia yang ke 73 pada tanggal 25 Agustus 2018. Mahasiswa kemudian ditarik kembali untuk melaksanakan pembelajaran. Pada tanggal 30 Agustus seluruh mahasiswa delakukan upacara penarikan mahasiswa yang dilaksanakan di BAPPEDA Kabupaten Temanggung.

\section{f). Hasil Pelaksanaan Kegiatan}

Kegiatan KKN di Desa Kedu, Kecamatan

Kedu, Kabupaten Temanggung dilaksanankan 
selama tiga puluh lima (35 hari) terhitung dari tanggal 25 Juli 2018 hingga 30 Agustus 2018. Kegiatan yang dilakukan selama KKN yaitu program kerja individu, program kerja kelompok, dan program kerja desa. Program kerja itu disusun oleh dosen dan mahasiswa yang dilaksanakan sebagai pengabdian kepada masyarakat.

\section{Capaian Kegiatan}

Secara kualitatif hasil pelaksanaan Kuliah Kerja Nyata (KKN) dan Pengadian Kepada Masyarakat di Desa Kedu, Kecamatan Kedu, Kabupaten Temanggung dapat terlaksana dengan baik dan sesuai dengan harapan. Hal ini terbukti dengan tercapainya semua program yang telah dilaksanakan. Pelaksanaan kegiatan-kegiatan dilaksanakan secara bersama-sama dan saling bantu-membantu dari prodi lain yang menyesuaikan dengan situasi dan kondisi masyarakat. Berikut merupakan penjabaran hasil kegiatan masing-masing individu peserta KKN 2018.

1. Penanaman Pohon Beringin disitus Keliangan.

Kegiatan Penanaman Pohon Beringin di situs Liyangan di ikuti oleh Mahasiswa KKN ISI Surakarta kelompok 8 Desa Kedu yang di dampingi oleh Ketua Desa Wisata dan Aparat Kepolisian, penanaman pohon ini diselenggerakan pada tanggal 26 Juli 2018 Jam 15.00-17.00.

tujuan dari kegiatan penanaman pohon beringin untuk dapat mengetahui peristiwa situs sejarah liyangan yang dilakukan bersama dengan tokoh masyarakat Desa Kedu khususnya Dusun Irawanan RW 4 dan dapat mengetahui tempat-tempat bersejarah serta dapat mengetahui destinasi wisata yang dimiliki oleh Kabupaten Temanggung.

Indikator keberhasilan dari kegiatan penanaman pohon beringin di situs Liyangan berjalan dengan lancar, Adapula sedikit hambatan dari kegiatan tersebut yaitu jarak antara desa Kedu dengan Lokasi terlalu jauh sehingga memakan waktu yang cukup lama.
2. Mengikuti Kegiatan Penyuluhan Anti Narkoba di Kelurahan Desa. Kedu.

Kegiatan sarasehan yang diselenggarakan di Kelurahan Kedu pada hari rabu 25 Juli 2018 bersama tokoh masyarakat Desa Kedu, capaian yang didapat dari penyuluhan tersebut dapat memahami keadaan lingkungan di desa Kedu terutama anak-anak, dimana kegiatan KKN begitu dekat dengan anak-anak, terutama anak-anak SD dan SMP, di dalam penyuluhan tersebut Mahasiswa KKN

Indikator keberhasilan dari kegiatan penyuluhan anti narkoba di kelurahan dapat berjalan dengan lancar, mahasiswa KKN menjalankan perintah dari desa untuk membantu mengawasi prilaku anak - anak dan remaja dilingkungan sekitar supaya tidak terjadi prihal penyalahgunaan dalam penggunaan narkoba Adapula sedikit hambatan dari kegiatan tersebut yaitu kurang waktu mendekatkan diri pada anak - anak dan remaja sekitar.

3. Kegiatan 17 Agustusan Di Dusun Irawanan.

a) Pengecetan Jalan Di Rw 04 Rt 01

Pengecetan jalan di Dusun Irawanan merupakan agenda tahunan yang dilakukan oleh warga setiap menjelan 17 Agustus, pada tahun 2018 warga menyerahkan sepenuhnya kepada Mahasiswa KKN untuk menghias serta mengecat jalan dan menghambar jalan yang ada di gang khususnya RW 04 Dusun Irawanan. kegiatan ini dilakukan dari awal bulan agustus hingga mendekati 17 Agustus yang di kerjakan pada siang dan malam hari serta menyesuaikan dengan jadwal kegiatan Mahasiswa KKN pada hari-hari lain.

Indikator keberhasilan dari kegiatan ini berjalan dengan lancar serta membuat kampung dusun Irawanan Rw 4 lebih berwarna dan terlihat lebih indah untuk penyambutan 17 -san, selain itu juga ada hambatan dalam proses pengerjaan salah satunya kekurangan Cat sehingga memperlambat proses pengerjaan. 
b) Jalan Santai Rw 04 Rt 01

Jalan santai merupakan salah satu agenda yang ada di dalam kegiatan 17-san, yang diselenggarakan oleh panitia dari Karang Taruna dusun Irawanan, dalam kegiatan jalan santai ini Mahasiswa KKN ikut membantu dalam proses persiapan sampai selesainya acara jalan santai.

- Mendekorasi panggung.

- Membantu menjadi panitia membagikan kupon JJS.

- Menjaga Posko di perlintasan Jalan santai.

Indikator keberhasilan dari kegiatan Jalan Santai berjalan dengan lancar dan Mahasiswa KKN bisa membantu karang taruna dan bisa mengenal satu sama lain. Adapula sedikit kendala dalam berjalannya kegiatan ini yaitu kurangnya koordinasi dari karang taruna dalam jalannya acara dan kurangnya persiapan selama acara berlangsung.

Adapun partisipasiuntuk membantu kegiatan lain yang di selenggaran oleh Karang Taruna Dusun Irawanan yaitu Lomba-lomba yang di ikuti oleh anak-anak sekitar Dusun Irawanan.

c) Pentas seni Malam 17 agustusan Di Rw 02 Rt 02

Dalam kegiatan ini mahasiswa KKN ikut berpartisipasi didalam berjalannya acara, capaian yang di dapat dalam acara ini adalah sebagai berikut:

1. Berpartisipasi untuk mengisi salah satu acara kesenian dibidang tari yaitu Tari Cublak - cublak Suweng yang di tariakan oleh anak -anak di desa kedu dengan jumlah 6 anak. Yaitu Gadis, Naya, Puput, Aira, Ata, dan Lintang.

2. Dokumentasi dalam Jalannya acara

Mahasiswa KKN ikut berpartisipasi dalam mendokumentasi di Acara tersebut.

1. Pentas Perpisahan Mahasiswa KKN ISI Surakarta.

Indikator keberhasilan dari kegiatan perpisahan Mahasiswa KKN adalah 90 persen. Keberhasilan tersebut terhitung hampir seluruh perserta KKN yang dapat terlibat dalam kegiatan ini, selain itu antusiasme masyarakat khususnya di Dusun Kahuripan, Irawanan dan Masyarakat sekitar yang ikut mengapresiasi kegiataan ini dengan sangat baik. 10 persen ketidakberhasilan terhitung dari teknis pelaksanaan yang kurang berjalan dengan lancar salah satunya kurangnya kepanitian selama acara berlangsung.ketidak berhasilan dikarenakan waktu pelaksanaan yang mundur hingga lebih dari satu jam, selain itu pelaksanaan pameran karya yang kurang mendapat perhatian dari panitia sehingga terdapat beberapa karya warga yang hilang.

Adapun susunan acara yang telah di susun oleh panitia dalam acara perpisahan Mahasiswa KKN antara lain sebagai berikut:

\begin{tabular}{|c|c|c|}
\hline NO & Acara & PENANGGUNG JAWAB \\
\hline 1 & Pembukaan & Wahyu Widi Atmoko \\
\hline 2 & Pameran Karya & $\begin{array}{l}\text { Rio Pambudi } \\
\text { Arian Muhtar Safa'at } \\
\text { Silviya Sukmawati } \\
\text { Feradita Dian Ratin R }\end{array}$ \\
\hline 3 & Fashion Show & Siti Rofika \\
\hline 4 & Tari Mbako & Maulida Fitrotin dan Rita Kasmara \\
\hline 5 & Sambutan Lurah & $\mathrm{MC}$ \\
\hline 6 & Teater Musikal & Safina Khansa dan Mega Radha \\
\hline 7 & Karawitan PWRI & Wahyu Widi dan Wahyu Widhayaka \\
\hline 8 & Dayakan & Maulida Fitrotin dan Wahyu Widi \\
\hline 9 & $\begin{array}{l}\text { Tarian } \\
\text { Kalimantan }\end{array}$ & Rita Kasmara Dewi \\
\hline 10 & Kuda Lumping & Maulida dan Wahyu widi \\
\hline 11 & Perfoming Art & Hafizd Multazam \\
\hline 12 & Penutupan & All Panitia \\
\hline
\end{tabular}

Susunan Panitia perpisahan KKN adalah.

\begin{tabular}{|c|l|c|c|}
\hline NO & \multicolumn{1}{|c|}{ NAMA } & JABATAN & PRODI \\
\hline 1 & Wahyu Widi Atmoko & Ketua Acara & Karawitan \\
\hline 2 & Maulida Fitrotin K. & Stage Manager & Seni Tari \\
\hline 3 & Silviya Sukmawati & Sekertaris & Seni Rupa Murni \\
\hline
\end{tabular}




\section{Abdi Seni Jurnal Pengabdian Kepada Masyarakat}

\begin{tabular}{|c|l|c|c|}
\hline 4 & Mega Radha Siwi & Bendahara & Etnomusikologi \\
\hline 5 & Feradita Dian Ratin R & Koordinator Lo & Desain Interior \\
\hline 6 & Safina Khansa & Perkap & Teater \\
\hline 7 & Wahyu Widhayaka & Perkap & Karawitan \\
\hline 8 & Rio Pambudi & Perkap & Desain Interior \\
\hline 9 & Arian Muhtar Syafa'at & Perkap & Kriya Seni \\
\hline 10 & Hafizd Multazam & Dokumentasi & TAV \\
\hline 11 & Angga Bakti Efendy & Dokumentasi & DKV \\
\hline 12 & Danny Agung & Dokumentasi & Fotografi \\
\hline 13 & Siti Rofika & Konsumsi & Batik \\
\hline 14 & Rita Kasmara Dewi & Konsumsi & Seni Tari \\
\hline
\end{tabular}

\section{Hasil Kegiatan Prodi Karawitan \\ Pelatihan Seni Karawitan Ibu-ibu PKK}

Pelatihan Seni Karawitan diadakan setiap hari Rabu dan Kamis bertempat di Aula PWRI pada pukul 14.00 - 16.00 WIB. Dalam pelaksanaannya, pertama kali yang dilakukan adalah mengingat materi yang sebelumnya telah diajarkan KKN tahun 2017. Materi yang disampaikan yaitu Ricik-Ricik Banyumas, Suwe Ora Jamu, dan Lesung Jumengglung. Pada awal pertemuan, pelaksana menyampaikan kepada ibu-ibu bahwa hasil pelatihan seni karawitan ini akan dipentaskan pada acara perpisahan Mahasiswa KKN ISI Surakarta di Desa Kedu.

\section{Mengajarkan Tembang Macapat Pada Anak Usia Sekolah Dasar}

Pelaksanaan program kerja dilaksanakan setiap hari Sabtupukul 07.30 - 09.00 untuk Kelas 4 SDN 1 Kedu dan 09.30 - 11.00 untuk

Kelas 5 SDN 1 Kedu. Pada awal tahap pelaksanaannya, anak-anak diajak untuk berkenalan terlebih dahulu dan dibuat ceria dengan kehadiran Mahasiswa KKN ISI Surakarta. Selanjutnya, anakanak dijelaskan pengertian tembang beserta jenisjenisnya. Kemudian mengenalkan dengan titilaras atau nada dalam Gamelan Jawa dan belajar untuk menyuarakan tiap-tiap nada. Sehingga pada saat pemberian materi tembang, anak-anak sudah ada gambaran suara nada-nada gamelan. Materi awal yang diberikan yaitu tembang dolanan seperti Suwe Ora Jamu dan Gambang Suling. Selain itu ada juga tembang macapat diantaranya Pangkur, Pocung, Kinanthi, dan Sinom

\section{Pelatihan Privat Macapat Untuk Lomba MAPSI}

Pelaksanaan pelatihan pertama dilaksanakan pada tanggal 7 Agustus 2018. Pertama kali yang dilatih adalah membaca titilaras atau nada gamelan. Setelah itu membaca materi loba dengan cara membaca dan menirukan tiap baris notasi tembang dengan meminta peserta menirukan arahan dari pelaksana program.

\section{Melatih Kelompok Seni Kuda Lumping,Tari Jaipong dan Dayakan}

Untuk mengajarkan Kelompok Seni Kuda Lumping dan Ndayakan, pelaksana melakukan survey terlebih dahulu tentang bagaimana keberadaan Kesenian Kuda Lumping dan ndayakan yang berada di dusun Kahuripan. Sebelum menjalankan program, pelaksana menemui RW, Kepala Dusun, dan ketua Kesenian untuk memohon ijin masuk dan mengikuti kegiatan di kelompok kuda lumping dan dayakan.

\section{Membuat Iringan Tari Mbako}

Awal pelaksanaan, saya membuat komposisi gendhing yang diperlukan untuk iringan tari mbako. Setelah susunan gendhing dibuat, baru dimulai rekaman di balai dusun Kahuripan. Rekaman dilakukan per bagian untuk nantinya disambung sesuai kebutuhan menggunakan aplikasi Adobe Audition. Setelah rekaman dibuat, kemudian di uji coba langsung bersama penari tari Mbako agar rekaman iringan tari mbako sesuai dengan gerakan tarinya.

\section{Prodi Tari : Seni Tari \\ Menciptakan Tari Mbako}

Temanggung merupakan daerah peghasil tembakau berkualitas. Namun tidak semua 
kemakmuran dirasakan langsung oleh petani tembakau. Tari Tembakau dibuat sebagai penggambaran bagaimana semangat dan perjuangan petani saat menemi ragam bentuk masalah budidaya tembakau.

Pengajaran tari tembakau diaplikasikan kepada siswa dan siswi SDN I Kedu, SDN 3 Kedu, dan anak-anak Dusun Kahuripan. Petani tembakau di tarikan oleh siswi dan gambaran dari kendala, masalah maupun hama ditarikan oleh siswa.

Tujuan dari dibentuknya tari ini adalah untuk meningkatkan kreatifitas dan kepercayaan diri bagi anak, mengembangka kepekaan serta daya cipta (kreasi) anak untuk mengekspresikan, dan merangsang daya imajinasi.

\section{Menciptakan Tari Jaipong}

Kuda Lumping di Temanggung merupakan kesenian yang sangat digemari oleh semua kalangan masyarakat. Kesenian ini diminkan oleh banyak orang yang menceritakan pasukan berkuda dan membawa kuda yang terbuat dari anyaman bambu sebagai properti. Dalam alur cerita yang terdapat dari beberapa komunitas adalah, kuda lumping asli yang dikemas menjadi sendratari dan kuda Lumping kreasi yang terkadang di sisipkan beberapa pertunjukan Bali seperti Leak, Barongan Bali, tari Burung. Selain untuk melestarikan budaya, sisipan pertunjukan digunakan untuk memenuhi tuntutan pasar yang semakin kuat antar komunitas. Di desa Kedu terdapat satu komunitas Kuda Lumping yaitu di Dusun Kahuripan yang diberinama Turoggo Satrio Manunggal. Mereka menggunakan versi kreasi.

Tujuan dari pembuatan Tari Jaipong dalam Tari Kuda Lumping adalah untuk menambah susunan pertunjukan di komunitas Turoggo Satrio Manunggal. Diselipkan tari Jaipong agar memiliki katakter yang berbeda dari komunitas yang lain

\section{Berlatih Tari Ndayakan}

Topeng Ireng atau Dayakan adalah bentuk tarian rakyat kreasi baru yang merupakan hasil metamorfosis dari kesenian Kubro Siswo. Topeng Ireng atau Dayakan hampir mirip dangan suku indian di amerika atau suku dayak di kalimantan. Nama Topeng Ireng sendiriberasal dari kata Toto Lempeng Irama Kenceng. Toto artinya menata, lempeng berarti lurus, irama berarti nada, dan kenceng berarti keras. Oleh karena itu, dalam pertunjukan Topeng Ireng para penarinya berbaris lurus dan diiringi musik berirama keras dan penuh semangat.

Di Desa Kedu mulai marak pembelajaran Tari Ndayakan. Namun yang terlihat mencolok yaitu di RW 6 dan RW 2. Di RW 6 sudah mulai berjalan dari satu tahun lalu rintisan KKN 2017 dan RW 2 dari sebulan yang lalu dengan memanggil pengajar dari lain derah.

Pada tahap pelaksanaannya, anggota kuda lumping Turonggo Satrio Manunggal diajak untuk berkenalan terlebih dahulu dan menyampaikan tujuan dari kehadiran Mahasiswa KKN ISI Surakarta. Selanjutnya, pelaksana mengamati terlebih dahulu Tari Ndayakan. Karena materi sudah ada dan siap, pelaksanaan hanya pada pembenaran pada teknik gerak.

\section{Prodi : Etnomusikologi \\ Mengajarkan Tangga Nada dan Membaca Notasi Angka Pada Siswa Kelas 5 SD Negeri 2 Kedu}

Pelaksanaan program kerja dilaksanakan setiap hari senin dan selasa pukul $11.00-12.30 \mathrm{di}$ kelas 5 SDN 2 Kedu. Pada awal tahap pelaksanaanya, anak-anak diajak untuk berkenalan dahulu dan dibuat senang serta antusias dengan kedatangan Mahasiswa KKN ISI Surakarta. Selanjutnya, anak-anak dijelaskan pengertian tangga nada dan bagaimana itu membaca notasi angka beserta mempraktikan sedikit membaca solmisasi (do, re, mi, fa, sol, la, si). Kemudian meminta anakanak menirukan nada pada solmisasi, sehingga dalam proses pemberian materi anak-anak sudah ada gambaran bagaimana membaca notasi angka dengan baik. Materi awal yang diberikan yaitu notasi angka lagu Tanah Airku. Selain itu ada juga lagu nasional serta lagu daerah lainnya yang juga menjadi materi dalam pengajaran membaca notasi angka ini. 


\section{Pelatihan Vokal Pada Salah Satu Komunitas} Kesenian Religi di RW.08 Desa Kedu

Pelatihan teknik vokal diadakan setiap hari rabu dan kamis jam 15.00 - 17.00. dalam pelaksanaannya pertama kali, yang dilakukan adalah memberikan arahan teknik pemanasan sebelum bernyanyi. Lalu memberikan pengantar tentang bagaimana saja teknik-teknik bernyanyi dengan benar, dengan diiringi praktik secara langsung supaya apa yang dismpaikan terserap oleh pemahaman. Kemudian setelah itu mulai menginjak pada materimateri yang akan dilatihkan.

\section{Pelatihan Vokal Musikal Pada Pertunjukan Teater Musikal Anak-Anak Dusun Irawanan}

Latihan dilakukan setiap hari secara fleksibel, artinya disini tidak ditentukan hari apa saja untuk latihannya, namun untuk jam latihan disepakati pukul 16.00 - 17.30. Kemudian Awal pelaksanaan latihan adalah memilih karakter tokoh mana saja yang bagus diperankan oleh masing-masing anak. Ketika tokoh sudah ditentukan, maka tahap selanjutnya mengajarkan nada vokal yang harus dinyanyikan oleh masing-masing tokoh. Serta mengarahkan harus bagaimana karakter suara diciptakan agar sesuai dengan karakter tokoh yang diperankan.

\section{Pelatihan Pembacaan Notasi Angka Dan Teknik Bernyanyi Dengan Benar Di SMP PGRI Kedu}

Pada awal tahap pelaksanaan program kerja ini adalah perkenalan diri kepada siswa-siswa, dan memberikan pengantar tentang materi keseluruhan yang akan diajarkan. Memberikan materi tentang solmisasi serta menjelaskan teknik pemanasan sebelum bernyanyi serta beberapa contoh teknik pemanasan suara, teknik pernafasan yang benar saat bernyanyi, serta teknik membaca notasi angka dengan benar supaya tidak menimbulkan suara fals atau suara yang tidak tepat dengan nadanya.

\section{Prodi : Teater \\ Melaksanakan Worskhop make-up cantik/ natural ibu-ibu PKK}

Mahasiswa-mahasiswi pelaksana Kuliah Kerja Nyata atau KKN memiliki program kerja yang sudah dipersiapkan jauh-jauh hari, namun dalam pelaksaannya belum tentu bekerja sempurna sesuai ekspetasi. Ada sebagian programkerja yang tidak terlaksana dan bahkan harus 'banting setir' karena beberapa faktor tertentu. Saat pelaksanaannyapun juga tidak lepas dari temanteman prodi lainnya, sehingga terjadi saling tolong dalam program kerja teman-teman yang lain.

Kegiatan yang sudah dilaksanakan sesuai dengan program kerja adalah:

Workshop dilaksanakan pada minggu pertama, tepatnya hari Minggu, 29 Juli 2018. Dilaksanakan pukul 14.00 sampai menjelang maghrib. Peserta yang ditargetkan adalah ibu-ibu PKK dan pemudi RW 04. Mengajari bagaimana dalam menggunakan make-up yang baik dan benar. Memberikan tips dan trik dalam make-up agar menjadi lebih baik lagi. Ibu-ibu dan pemudi diminta untuk make-up dirinya sendiri dan diharap mampu terus menjaga penampilan make-up-nya.

\section{Pentas Teater Musikal anak-anak RW}

Pentas kali ini saya berkolaborasi dengan prodi etnomusikologi. Pada tahapan awal kami menentukan naskah yang akan dibawakan, saling bertukar pikiran untuk konsep garapan naskah. Pembagian tugas masing-masing sesuai dengan bidang studi. Mengumpulkan anak-anak dan mengajaknya untuk ikut berlatih teater.

Latiahan dilaksanakan dua sampai tiga hari dalam satu minggu, dilaksankan pukul 16.00 hingga menjelang maghrib. Dialog yang dinyanyikan menjadikan latihan lebih mudah dan seperti bermain, dikarenakan juga sudah saling kenal dengan anakanak sehingga mudah dalam mengatur. Saya mengajari tentang ekspresi dan gerak tubuh juga blocking. Mega membenarkan nada dalam pengucapan dialog dan beberapa blocking, kami 
juga sering bertukar pikiran agar pentas dapat terlaksana dengan baik. Hingga akhirnya naskah dipentaskan dalam Pentas Penutupan Kedu Gembira pada tanggal 28 Agustus 2018.

\section{Mengajari siswa-siswi SD kelas $V$ dasar menggambar garis horisontal, vertikal, diagonal, dan kotak-kotakdan menggambar hitam putih}

Mengajari siswa-siswi SD kelas V dasar menggambar garis horisontal, vertikal, diagonal, dan kotak-kotak dengan penggaris. Setelah mampu melalui menggambar garis, siswa-siswitersebut saya ajari menggambar perpotongan flora dan fauna, kemudian diwarnai hitam dan putih, sebelumnya tentu saya memberi contoh kepada siswa-siswi tersebut. Pelajaran ini dilaksanakan dua kali dalam satu minggu untuk tiap materi yang diberikan. Hasil akhir dalam menggambar tersebut kemudian diambil nilainya untuk nilai ujian sekolah.

\section{Prodi : Kriya Seni}

\section{Workshop Pyrografi (Lukis Bakar) Gantungan} Kunci kepada Murid SMK dan SMP PGRI

Pyrografi merupakan teknik lukis dimana menggunakan alat yang menghasilkan panas untuk membuat efek luka bakar pada kayu. Seni lukis ini biasa digunakan untuk membuat souvenir. Berbagai souvenir bisa dihasilkan menggunakan teknik lukis bakar. Dari gantungan kunci, papan nama, sketsa wajah dan lain sebagainya sesuai kreatifitas.

Kegiatan workshop ini bertujuan mengajak pelajar untuk produktifmemanfaatkan waktu luang dan berfikir kreatifmemanfaatkan kayu bekas untuk dibuat souvenir, dan menghasilkan keuntungan yang bisa dimanfaatkan.

Target workshop ini merupakan pelajar yang usianya remaja, jadi mengambil 40 murid dan beberapa guru dari SMP dan SMK PGRI Kedu sebagai peserta workshop pyrografi.

Pelaksanaan workshop pyrografi dilakukan sekali, yaitu di hari kamis tanggal Kamis tanggal 2 Agustus 2018. Adapun proses workshop pyrografi diantaranya :
Materi sejarah singkat dan latar belakang pengadaan workshop pyrografi.

Materi mengenai teknik dasar lukis bakar kepada siswa-siswi dan menjelaskan alat dan bahan yang digunakan serta proses lukis bakar. Mengelompokkan menjadi 2 bagian, yaitu SMP dan SMK. Selanjutnya pembagian bahan untuk medium lukis bakar.

Membuat sketsa diatas permukaan kayu yang sudah disediakan sesuai keinginan. Disini dilakukak pembimbingan per individu.

Dilanjutkan proses pembakaran menggunakan solder yang sudah disediakan secara bergantian. Tahap terakhir pemasangan gantungan kunci.

\section{Mural Jalan Rw 4 Rt 1}

Kegiatan program kerja ini merupakan permintaan dari ketua $\mathrm{Rw} 4$ pada rapat bulanan $\mathrm{Rw}$ pada hari Senin tanggal 6 Agustus 2018. Dikegiatan rapat tersebut membahas tentang kegiatan untuk memeriahkan hari kemerdekaan dan menyambut hari raya kurban. Disitulah anak KKN diminta untuk menghias jalan dengan warna atau disebut mural. Kegiatan mural bertujuan untuk memperingati hari Kemerdekaan Republik Indonesia yang ke-73. Mural ini bertemakan budaya lokal yang mengambil bentuk motif ceplok/mandala dan tokoh punokawan diantaranya semar, gareng, petruk dan bagong. Penyesuaian jadwal program kerja yang lain.

\section{Mengajar Nirmana dan Dasar Gambar Bentuk di SDN 2 dan 3 Kedu}

Pada tahap ini penulis melakukan riset lapangan yang ada di sekolah dasar tersebut, persiapan yang di lakukan penulis ialah membuat rancangan jadwal yang sesuai dengan jadwal yang ada di sekolah dasar sehingga program kerja tidak menganggu jadwal kegiatan belajar mengajar di sekolah dasar. Persiapan yang lain yang harus dilakukan ialah memilah antara kelas 4-6 karena menyesuaikan umur dan materi yang di berikan tentunya juga berbeda. Penulis melakukan kegiatan belajar mengajar ini setiap hari senin sampai dengan hari kamis dengan waktu sehari selama 2 jam 
pembelajaran, diminggu pertama dan kedua pemberian materi dasar dan minggu ketiga dan keempat praktek menggunakan kertas gambar.

\section{Mengajar Ornamen dan Grafiti di SDN 2 Kedu}

Program kerja mengajar ornamen dan grafiti terfokus pada target anak-anak. Sebelumnya penulis melakukan observasi menentukan sekolah yang cocok untuk mengajar onamen dan grafiti. Penulis tertuju pada Sekolah Dasar Negeri 2 Kedu yang merupakan sekolah favorit di daerah kedu, meminta izin dan kesepakatan waktu yang pas supaya tidak mengganggu kegiatan belajar mengajar.

\section{Mural Balai Dusun Kahuripan Kelurahan Kedu}

Pengadaan mural di balai dusun Kahuripan difungsikan untuk memeriahkan penutupan dan sebagai peninggalan mahasiswa KKN di dusun Kahuripan. Mural di balai dusun difungsikan sebagai penghias agar lebih menarik dan tidak terkesan sepi.

Tema yang digunakan merupakan kebudayaan daerah yaitu kuda lumping yang penggambarannya dengan bentuk dua kuda lumping yang saling berhadapan seakan hidup.

\section{Prodi : Batik \\ Pelatihan Pembutan Batik Jumputan}

Sebelum program kerja dilaksanakan, pelaksana terlebih dahulu menemui Kepada Desa dan warga di Kelurahan, serta meminta izin untuk melaksanakan kegiatan beserta menentukan target peserta secara spesifik dan menjelaskan target capaian dari Program Kerja yang akan dilaksanakan, target yang terkait dalam pelatihan Batik Jumputan ini adalah Siswa-siswi SDN 1 Kedu.

Pelatihan batik jumputan bertujuan memberi pengetahuan baru dalam seni mewarnai kain mori dengan menggunakan teknik jumput, mengikat kain dan memberi warna.

Sebelum pelatihan dilaksanan pertama observasi ke Sekolah terlebih dahulu, pada tanggal
30 Juli 2018 berkunjung ke SDN 1 Kedu untuk bertemu dengan Kepala Sekolah serta Dewan Guru lainnya meminta izin utuk pelaksanaan pelatihan batik Jumputan, pihak sekolah menyetujui dan menentukan jadwal kegiatan pelatihan tersebut sehingga tidak bentrok dengan jadwal pelajaran di Sekolah, Kepala Sekolah menyetujui untuk memberikan pelatiha Batik Jumputan kepada Siswa kelas 5 dengan Jumlah 25 Siswa.

\section{Pelatihan Batik Tulis}

Sebelum program kerja dilaksanakan, pelaksana terlebih dahulu menemui Kepada Desa dan warga di Kelurahan, serta meminta izin untuk melaksanakan kegiatan beserta menentukan target peserta secara spesifik dan menjelaskan target capaian dari program kerja yang akan dilaksanakan, target yang terkait dalam pelatihan Batik Tulis ini adalah Siswa-siswi SDN 1 Kedu dan SDN 2 Kedu. Dalam pelatihan ini merupakan permintaan setiap Sekolah Dasar karena merupakan proses pembelajaran untuk persiapan lomba Membatik atau FLS2N yang merupakan agenda lomba tahunan tingkat SD.

Pelatihan Batik Tulis bertujuan memberi pengetahuan mengenai perkembangan motif yang sudah ada maupun masih baru.

Sebelum pelatihan dilaksanan pertama observasi ke Sekolah terlebih dahulu, pada tanggal 27 Juli 2018 berkunjung ke SDN 2 Kedu dan 30 Juli 2018 SDN 1 Kedu untuk bertemu dengan Kepala Sekolah serta Dewan Guru lainnya meminta izin utuk pelaksanaan pelatihan Batik Tulis dan menentukan jadwal kegiatan pelatihan tersebut sehingga tidak bentrok dengan jadwal pelajaran di Sekolah, Batik Tulis ini diberikan kepada Siswa SDN 1 Kedu kelas 5 dengan Jumlah 22 Siswa dan SDN 2 Kedu kelas 4 dan 5 denganjumlah 14 Siswa.

Tahap pelaksanaan Batik Tulis ini dilaksanakan dalam seminggu 2 kali pertemuan SDN 1 Kedu hari Rabu dan Sabtu, SDN 2 Kedu Senin dan Selasa samapai minggu terakhir mendekati penutupan $\mathrm{KKN}$ pelatihan ini dimulai dari jam 11.00 - 15.00 di setiap masing-masing sekolah sesuai dengan Jadwal yang sudah di kesepakati. 


\section{Prodi : Desain Interior}

\section{Membuat Pameran dalan Acara Perpisahan KKN}

Pelaksana terelebih dulu mengajar di sekolah dasar SDN 3 dan SDN 2 dengan materi mengambar dan ketrampilan. Mengajar satu minggu sekali sampai dengan 4 pertemuan. Pelaksana juga menentukan siteplan dan sirkulasi ruang untuk pameran karya dalam acara perpisahan KKN. Kemudian mentukan bahan material yang di apakai untuk mengantung karya dan cara mendisplay karya tersebut dengan mengunakan rigen.

Pertama - tama pelaksana di bantu warga dan muda - mudi kauripan memasang panggung bergotong royong saling membantu memasang panggung, setelah terpasang kemudian memasang tratak untuk atap panggung setelah itu baru mulai mendekor.

Konsep dekorasi panggung perpisahan KKN mengakat konsep dari tembakau yang menjadi ikon temangung. Di desa kuripan mayoritas masyarakat juga bertanitembakau jadi itu menjadi alasan pemilihan konsep tembakau kemudian pemilihan warna putih agar terlihat mewah karna ada nya tamu undangan yang penting dan sepesial. Di beri aksesoris merah putih juga karena masih hangat

\section{Prodi : DKV}

\section{Pembuatan dan Pelatihan Pengelolaan Media Sosial Untuk Desa Wisata Kedu}

Media sosial merupakan cara yang paling efektif untuk memberitakan suatu hal atau berita karena pada saat ini sedang banyak digunakan oleh masyarakat dunia maya atau sering disebut warganet atau netizen, media sosial yang sering digunakan adalah Instagram dan Youtube maka dari itu kami mencoba untuk mulai memanfaatkan kedua sosial media itu untuk keperluan publikasi Desa Wisata Kedu agar lebih terekspos lebih luas, kedua media sosial diatas memiliki karakteristik yang berbeda, jika Instagram adalah media sosial berbasis berbagi foto dengan caption, Youtube lebih kompleks lagi karena dapat berbagi konten berupa gambar bergerak atau video. Media sosial disini selain untuk mewacanakan potensi desa Kedu kepada khalayak luas dengan pengolahan konten yang menarik juga dapat digunakan sebagai sarana penghubung antar masyarakat, dengan cara mengantarkan informasi antar desa saat menyampaikan pengumuman.

Di desa Kedu juga mayoritas masyarakatnya merupakan masyarakat dengan SES B tentu saja jika berbicara tentang media sosial bukan lagi menjadi kendala, karena berdasarkan pantauan kami, sebagian besar anak muda dan bapak ibu di Kedu sudah memiliki akun Google dan Instagram aktif, sangat memungkinkan untuk diasah agar dapat menghasilkan konten tentang desa yang baik.

Tujuan dari kegiatan ini adalah mengajak masyarakat untuk aktif dan bijak dalam menggunakan media sosial, sehingga informasi antar dusun dapat lebih efektif dan cepat menyebar, serta segala informasi tentang desa Kedu dapat terwacanakan dengan lebih luas dan baik sehingga ber-impact luas terhadap perkembangan potensi daerah Kedu sebagai Desa Wisata.

Lembaga yang terkait di dalam program ini adalah Pemuda Desa atau Karang Taruna Desa Kedu kecamatan Kedu Kabupaten Temanggung. Bentuk kegiatannya adalah pelatihan pembuatan konten dan pengelolaan media sosial secara benar dan tepat sasaran.

Dengan ini strategi pemasaran berita yang akan dilakukan mampu menjawab keinginan target audience.

Melihat kegiatan dan potensi desa yang akan dijadikan sebagai acuan pembuatan konten media sosial merupakan tahap awal yang harus dilaksanakan. Perancangan konten dilakukan sesuai pola masyarakat, kegiatan, kebiasaan, dan kesenian yang ada. Dengan pembagian tema tersebut membantu penulis untuk memisahkan faktor penting dari potensi desa. Pembuatan dan penguploadan konten berjalan sesuai dengan kegiatan dan tema konten. Tahap terakhir adalah mengedukasi karang taruna dan kelompok pemuda dalam membuat konten yang lebih menarik dan berisi, sehingga nantinya dapat dijadikan arsip desa yang tertata dan 
efektif. Pengumpulan materi dilakukan setiap hari dengan metode door-to-door yaitu dengan mendatangi satu persatu potensi desa Kedu dengan bantuan warga lokal dan kelompok pemuda sebagai narasumber dalam penulisan caption disamping metode wawancara yang selalu kami gunakan sebagai andalan dalam penulisan sebuah caption

Pelatihan dan Sharing Fotografi dalam upaya Pembuatan Konten Sosial Media yang baik.

Kami berusaha untuk memberikan yang terbaik untuk Kedu, terlebih dalam pewacanaan desa wisata Kedu harus konsisten dan akurat dengan konten-konten yang menarik, kami mengajak anak-anak muda yang giat bersosial media dan futuristik untuk memproduksi konten bersama mengangkat potensi daerah Kedu menjadi nilai jual yang lebih, yang nantinya akan berguna jika ada wisatawan yang mencari info tentang Kedu.

\section{Prodi : Fotografi}

\section{Dokumentasi Kegiatan dan Dokumentasi Potensi Desa}

Melihat potensi desa yang sangat menjajikan untuk di eksplor dari segi budaya, ekonomi, potret desa Keblukan dan banyaknya program yang dikerjakan oleh mahasiswa KKN desa Kedu, maka perlu adanya pemanfaatan dokumentasi dalam bentuk visual (foto) agar semua hal di desa Kedu dapat terekam.

Semua kegiatan yang di lakukan oleh mahasiswa KKN ISI Surakarta di desa bisa di abadikan melalui media fotografi dan fotogafi juga menjadi media untuk mendokumentasikan potensi Desa Kedu.

Lembaga yang terkait di dalam program ini adalah Potensi Desa Kedu Kecamatan Kedu Kabupaten Temanggung. Bentuk kegiatannya adalah Dokumentasi.

Berikut adalah tahapan pelaksanaan program ini sebagai berikut:

Melihat potensi desa dibagi menjadi beberapa tema yaitu Lancape desa, aktivitas masyarakat, organisasi masyarakat dan potensi ekonomi.Dengan pembagian tema tersebut membantu untuk memisahkan faktor penting dari potensi desa.Selain itu pendokumnetasian kegiatan mahasiswa ISI Surakarta yang KKN di desa Kedu berjalan seiring dengan berjalannya program kerja yang di lakukan oleh mahasiswa.

Program ini berjalan secara berkelanjutan sampai penarikan KKN ISI Surakarta pada 30 Agustus 2018.

\section{Prodi : Seni Rupa Murni \\ Pelatihan menggambar Ayam Cemani Pelatihan Menulis Arab (Khot)}

Sebelum program kerja dilaksanakan, pelaksana terlebih dahulu menemui, serta meminta izin untuk melaksanakan kegiatan beserta menentukan target peserta secara spesifik dan menjelaskan target capaian dari program kerja yang akan dilaksanakan, target yang terkait dalam pelatihan Penulisan Arab adalah Siswa-siswi SDN 2 Kedu. Berkaitan dengan lomba FL2SN guru SDN 2 Kedu meminta mahsiswa KKN untuk mendampingi dan memberikan pelatihan kepada siswa-siswi SDN 2 Kedu.

Pelatihan Menulis Arab bertujuan untuk memperdalam ilmu agama dalam bidang penulisan Arab dan memberi pengetahuan mengenai tata cara menulis arab yang baik dan benar.

\section{Mural (Lukis Dinding)}

Sebelum program kerja dilaksanakan, pelaksanaan terlebih dahulu yaitu menemui Kepala Sekolah Kelompok Bermain Pelita Bangsa Kedu,meminta izin untuk melaksanakan kegiatan Mural di dinding sekolah pelita bangsa.Mural dimulai pada tanggal pada tanggal Hari Selasa 21 Agustus 2018 sampai29 Agustus 2018

\section{Prodi : Televisi Dan Film \\ Membuat Video dan Dokumentasi}

Setiap mahasiswa dari setiap program studi sudah memiliki rencana program kerja, sebelum melakukan program kerja kelompok KKN melakukan persiapan Program kerja. Sebagai mahasiswa Televisi dan Film yang erat dengan dunia 
video, lebih mencari informasi mengenai kebutuhan desa yang bersangkutan dengan media video

Wawancara dan observasi mandiri dilakukan di awal kegiatan KKN Untuk mendapatkan informasi mengenai potensi potensi yang ada di desa Kedu.. Data yang didapatkan dapat dijadikan materi untuk pembuatan video profil desa dan program kerja yang lain. Dalam tahap ini mahasiswa juga menemukan kegiatan-kegiatan masyarakat dan hal hal yang masih jarang diketahui serta ciri khas desa tersebut.

- Membagi skala prioritas kegiatan dari skala kecil dan besar. Kemudian menentukan kegiatan mana yang harus didahulukan dan kegiatan yang harus dibuat dokumentasi video dan mana yang cukup dengan dokumentasi berupa foto saja.

- Meminta bantuan dari mahasiswa program studi fotografi dan DKV Untuk membantu mendokumentasi dengan video setiap kegiatan yang terlaksana

- Penjadwalan kegiatan yang dibuat padat agar bisa selesai tepat waktu dan meminta bantuan mahasiswa pogram studi lain untuk memudahkan dalam pengerjaan.

\section{KESIMPULAN}

Program Pengabdian Masyarakat dan Kuliah Kerja Nyata diselengarakan di masyarakat secara langsung oleh mahasiswa KKN ISI Surakarta. Dengan adanya program kuliah kerja nyata, dapat memberikan dampak yang positif bagi semua kalangan masyarakat dan pihak penyelengara. Kegiatan Kuliah Kerja Nyata yang dilaksanakan oleh mahasiswa ISI Surakarta yang bertempat di desa Kedu berjalan dengan lancar, rencana program kerja yang sudah disusun dapat berjalan dengan baik, walaupun terdapat beberapa rencana kegiatan mengalami adanya hambatan dari beberapa faktor. Kendala tersebut dapat ditangani dengan solusialternatif didalam programkerja yang sudah dibuat. Program baru ini juga akan menjadi salah satu kegiatan yang mendorong kesuksesan dan keberhasilan KKN tidak terlepas dari kerjasama antara mahasiswa dan masyarakat setempat dan perangkat Desa. Pelaksanaan KKN dan PKM, mahasiswa dapat belajar bersosialisasi dengan lingkungan yang baru dan ikut dalam pengembangan potensi Desa, serta majasiswa dapat mencari solusi dalam menghadapi berbagai hambatan sekaligus melatih kebijaksanaan dan pendewasaan diri.

Hasil dari program KKN dan PKM ini, mahasiswa dapat memberdayakan masyarakat untuk berpikir secara modern dan terbuka dengan adanya sesuatu yang baru. Sikap yang terbuka dan motivasi yang besar dapat mengembangkan sistem sosial masyarakat serta potensi kesenian yang dimilikinya. Program kerja semacam ini dapat dilaksanakan oleh masyarakat secara berkesinambungan, maka masyarakat tercapai kesejahteran sosial yang berorientasi pada kearifan lokal.

\section{DAFTAR PUSTAKA}

Nanik Sri Prihatini. "Eksistensi Pertunjukan Kuda Kepang Di Lereng Gunung Sumbing Jawa Tengah Menuju Ke Sebuah Identitas". Artikel dalam Jurnal Greget Jurnal Ilmu dan Seni ISI Surakarta Vol.6. No. 1 Juli 2008

Jazuli, M. Sosiologi Seni. Surakarta: UNS Pres. 2012

Soedarsono Seni Pertunjukan dan Pariwisata Rangkuman Esai tentang Seni Pertunjukan Indonesia dan Pariwisata. Yogyakarta: BP ISI. 1999.

Subandi Upacara Bersih Dusun Ngagrong Atas, Desa Ngagrong Ampel Boyolali. Surakarta: Gelar Volume 9 No . 1 Juli. 2011

Suharji "Transformasi Seni Tradisi di Era Globalisasi" Proseding SeminarNasional 15 Oktober 2012. Paradigma Perguruan Tinggi Seni Sebagai Kesadaran Kolektif Menghadapi Globalisasi. 2012

Sutopo, Hb. Metode Penelitian Kualitatif. Surakarta: UNS Press. 2006 
Abdi Seni Jurnal Pengabdian Kepada Masyarakat

Soemaryatmi. Dampak Akulturasi Budaya Pada Kesenian Rakyat Kecamatan Selo Boyolali dalam Panggung Jurnal Seni dan Budaya. Bandung: STSI. Vol 22. No. 1. Januari-Maret. 2012
Pertunjukan Tari Campur Bawur Tradisi Syawalan Desa Lencoh Sela Boyolali dalam Harmonia Jurnal Pengetahuan dan Pemikiran Seni. Semarang: UNNES Vol. X. No. 1 Juni. 2010. 